\title{
PENGARUH KECERDASAN EMOSIONAL GURU, KARAKTERISTIK PEKERJAAN DAN KEMATANGAN EMOSI TERHADAP KINERJA GURU DI MADRASAH TSNAWIYAH NEGERI 3 KABUPATEN SIMALUNGUN
}

\author{
${ }^{1}$ Dedi Kuswadi, ${ }^{2}$ Getty Situmorang, ${ }^{3}$ Layla Ramadhani, ${ }^{4}$ Muhammad Ihsan, ${ }^{5}$ Watnika Purnama Sari \\ $1,2,3,4,5$ Universitas Islam Sumatera Utara \\ 11 dedi.kuswadi@gmail.com, ${ }^{2}$ getty.situmorang@gmail.com, ${ }^{3}$ layla.ramadhani@gmail.com, ${ }_{5}^{4}$ mhd.ihsan@gmail.com, \\ ${ }^{5}$ watnika.purnamasari@gmail.com
}

\begin{abstract}
The problem formulation of this research is how the influence of teacher emotional intelligence on teacher performance. How the characteristics of the work affect the performance of teachers. How emotional maturity affects teacher performance. How the teacher's emotional intelligence, work characteristics and emotional maturity affect the teacher's performance. The purpose of this study was to find out the influence of teacher's emotional intelligence on teacher performance. To find out the effect of work characteristics on teacher performance. To know the effect of emotional maturity on teacher performance. To find out the influence of the teacher's emotional intelligence, work characteristics and emotional maturity on the teacher's performance. The sample in this study amounted to 39 teachers. The data analysis techniques used in this study are descriptive analysis and multiple linear regression analysis. The results of this study explain that the variables of the teacher's emotional intelligence have a positive and significant effect on the teacher's performance. The variable characteristics of the work have a positive and significant effect on the teacher's performance. Variable emotional maturity has a positive and significant effect on teacher performance. The teacher's emotional intelligence variables, work characteristics and emotional maturity have a positive and significant effect on the teacher's performance.
\end{abstract}

Keywords : Emotional intelligence, Job characteristics, Emotional maturity, Performance

ABSTRAK : Rumusan masalah penelitian ini adalah bagaimana pengaruh kecerdasan emosional guru terhadap kinerja guru. Bagaimana pengaruh karakteristik pekerjaan terhadap kinerja guru. Bagaimana pengaruh kematangan emosi terhadap kinerja guru. Bagaimana pengaruh kecerdasan emosional guru, karakteristik pekerjaan dan kematangan emosi terhadap kinerja guru. Tujuan penelitian ini adalah untuk mengetahui pengaruh kecerdasan emosional guru terhadap kinerja guru. Untuk mengetahui pengaruh karakteristik pekerjaan terhadap kinerja guru. Untuk mengetahui pengaruh kematangan emosi terhadap kinerja guru. Untuk mengetahui pengaruh kecerdasan emosional guru, karakteristik pekerjaan dan kematangan emosi terhadap kinerja guru. Sampel dalam penelitian ini berjumlah 39 orang guru. Teknik analisis data yang digunakan dalam penelitian ini adalah analisis deskriptif dan analisis regresi linier berganda. Hasil penelitian ini menjelaskan bahwa variabel kecerdasan emosional guru berpengaruh positif dan signifikan terhadap kinerja guru. Variabel karakteristik pekerjaan berpengaruh positif dan signifikan terhadap kinerja guru. Variabel kematangan emosi berpengaruh positif dan signifikan terhadap kinerja guru. Variabel kecerdasan emosional guru, karakteristik pekerjaan dan kematangan emosi berpengaruh positif dan signifikan terhadap kinerja guru.

Kata kunci : Kecerdasan emosional, Karakteristik pekerjaan, Kematangan emosi, Kinerja

\section{Pendahuluan}

Berdasarkan Undang-Undang No. 20 tahun 2003 tersebut sangat jelas peranan guru sangat penting. Sebagai salah satu komponen dalam proses belajar mengajar guru memiliki posisi yang sangat menentukan keberhasilan pembelajaran dalam merancang, mengelola, melaksanakan dan mengevaluasi pembelajaran. 
Guru juga memiliki kedudukan sebagai figur sentral dalam meningkatkan proses belajar mengajar. Di tangan para gurulah terletak kemungkinan berhasil atau tidaknya pencapaian tujuan belajar mengajar di sekolah, serta di tangan mereka pulalah bergantungnya masa depan karir peserta didik yang mempunyai sejumlah kepandaian dan kecakapan tentang sesuatu yang dapat membentuk kematangan pribadinya.

Namun realitas yang terjadi ternyata kualitas guru pada saat ini masih banyak dibicarakan orang, baik di kalangan para pakar pendidikan maupun di luar para pakar pendidikan. Selama dasawarsa terakhir ini media massa cetak, elektronik memuat berita tentang guru. Ironisnya berita-berita tersebut banyak yang cenderung merendahkan martabat guru, baik yang sifatnya menyangkut kepentingan umum sampai kepada hal-hal yang sifatnya sangat pribadi, sedangkan dari pihak guru sendiri nyaris tidak mampu membela diri. Sebagaimana kejadian di SMA Negeri 10 Yogyakarta garagara seorang guru menendang siswa yang telat masuk sekolah dan memberikan hukuman terhadap siswa tersebut. Karena guru kurang bisa mengendalikan emosinya, siswa tersebut mengadukan kepada orang tuanya perihal kejadian di sekolah. Merasa tidak terima dengan perlakuan guru, orang tua siswa melaporkan kejadian itu ke Dewan Pendidikan yang akhirnya guru itu dimutasi.

Ada beberapa faktor yang dapat mempengaruhi kinerja guru di Madrasah Tsanawiyah Negeri 3 Kabupaten Simalungun, salah satu faktornya adalah kecerdasan emosional. Goleman (2011:44), mengemukakan bahwa kecerdasan emosional menentukan posisi seseorang mempelajari ketrampilanketrampilan praktis yang didasarkan pada lima unsur, yaitu : kesadaran diri, motivasi diri, pengendalian diri, empati dan ketrampilan dalam membina hubungan.

Menjadi guru bisa jadi adalah pekerjaan yang mudah jika setiap guru berprinsip bahwa dalam mengajar yang terpenting adalah telah tersampaikannya sebuah materi pelajaran. Mau dipahami atau tidak dipahami oleh siswa itu masalah lain, bahkan mau didengar atau tidakpun, masa bodoh. Maka gampang sekali jadi guru seperti itu, siapapun bisa menjadi guru. Namun yang ideal tidaklah demikian. Sebaliknya menjadi guru adalah pekerjaan yang berat, karena kesulitan yang terbesar dihadapi guru bukan semata dalam hal menyampaikan materi pelajaran, akan tetapi dalam hal bagaimana ia mengenal dan memahami karakter dan emosi anak didiknya. Banyak kasus yang mencoreng nama guru itu karena para guru tak paham karakter siswanya, kurang sabar dalam mengajar. Guru yang tidak bisa mengontrol emosinya dengan baik, sering terpancing untuk memarahi peserta didiknya di kelas bahkan melakukan kekerasan pada siswa. Berbeda dengan seorang guru yang bisa mengontrol emosi dengan baik, jika muridnya melanggar ia mencoba untuk memahami perbuatan itu. Kestabilan emosi sangat diperlukan, namun tidak semua orang mampu menahan emosi terhadap rangsangan yang menyinggung perasaan, dan memang diakui bahwa setiap orang mempunyai temperamen yang berbeda dengan orang lain. Kriteria guru yang cerdas emosinya antara lain : empati, mengungkapkan dan memahami perasaan, mengendalikan amarah, kemandirian, kemampuan menyesuaikan diri, disukai, kemampuan memecahkan masalah antarpribadi, kesetiakawanan, keramahan, sikap hormat. Hal ini diperkuat dengan hasil penelitian terdahulu dari Devi, R. (2012); Fauzi, A. (2013); Firdaus, D. (2012) dan Lisda, R. (2012), kesemuanya menyatakan kecerdasan emosional berpengaruh positif terhadap kinerja.

Selain kecerdasan emosional, yang mempengaruhi kinerja guru di Madrasah Tsanawiyah Negeri 3 Kabupaten Simalungun adalah karakteristik pekerjaan. Menurut Schuler (2011:55), karakteristik pekerjaan adalah upaya mengidentifikasikan karakteristik tugas dari pekerjaan, bagaimana karakteristik itu digabung untuk membentuk pekerjaan yang berbeda dan hubungannya dengan kinerja guru. Karakteristik pekerjaan berkaitan dengan cara bagaimana para guru menilai tugas-tugas dalam pekerjaannya. Guru menilai pekerjaannya melalui persepsi mereka apakah pekerjaan tersebut sesuai dengan keinginannya. Karakteristik pekerjaan akan dapat mengoptimalkan motivasi dan kepuasan kerja guru yang pada akhirnya dapat meningkatkan kinerja. Sekolah perlu memahami karakteristik pekerjaan yang diperlukan sekolah dan gurunya. Karakteristik pekerjaan seorang guru di Madrasah Tsanawiyah Negeri 3 Kabupaten Simalungun masih jauh dari harapan. Karakteristik pekerjaan yang belum dicapai guru antara lain, adanya beberapa guru yang belum bertanggungjawab atas pekerjaannya seperti 
membuat RPP dengan menjiplak guru sekolah lain, belum bisa mengoperasikan berbagai macam media pembelajaran, tidak berani mengambil keputusan secara mandiri misalnya guru belum mampu memotivasi siswa dan menghidupkan suasana pembelajaran di kelas dengan baik, jarangya mendapat umpan balik berupa dukungan maupun kritikan terhadap guru tentang proses pembelajaran, dan belum adanya waktu khusus bagi siswa untuk berinteraksi khusus dengan guru di luar jam pelajaran. Penelitian terdahulu dari Firman (2011) dan Hartiwi (2016), keduanya menyatakan bahwa karakteristik pekerjaan berpengaruh positif terhadap kinerja.

Faktor lainnya yang mempengaruhi kinerja guru di Madrasah Tsanawiyah Negeri 3 Kabupaten Simalungun adalah kematangan emosi. Menurut Suryana (2012:88) kematangan emosi adalah kemampuan individu untuk dapat mengontrol dan mengendalikan emosi yang dimilikinya. Chaplin (2011:165) mengartikan kematangan emosi sebagai suatu keadaan atau kondisi mencapai tingkat kedewasaan dari perkembangan emosional, dan karena itu pribadi yang bersangkutan tidak lagi menampilkan pola emosional seperti masa kanak-kanak Kematangan emosi mempunyai cirri-ciri penerimaan diri yang baik individu yang memiliki kematangan emosi akan dapat menerima kondisi fisik maupun psikisnya, baik secara pribadi maupun secara sosial, dan kemampuan dalam mengontrol emosi dorongan yang muncul dalam diri individu untuk melakukan sesuatu yang bertentangan dengan nilai-nilai yang berlaku akan dapat dikendalikan dan diorganisasikan ke arah yang baik. Fenomena tentang kematangan emosi guru di Madrasah Tsanawiyah Negeri 3 Kabupaten Simalungun diantaranya guru kurang memahami visi, misi, sasaran dan tujuan organisasi, sebagian guru kurang bersikap sabar jika ada masalah dalam pekerjaannya.

\subsection{Batasan Masalah}

Agar permasalahan yang dikaji terarah maka permasalahan yang diteliti tentang faktor kecerdasan emosional guru. karakteristik pekerjaan dan kematangan emosi yang secara partial/simultan memberikan kontribusi ataupun tidak terhadap kinerja guru.

\subsection{Hioptesis}

Hipotesis adalah jawaban sementara terhadap masalah penelitian, yang kebenarannya harus diuji secara empiris. Hipotesis dalam penelitian ini adalah :

1) Kecerdasan emosional berpengaruh positif dan signifikan terhadap kinerja guru di Madrasah Tsanawiyah Negeri 3 Kabupaten Simalungun.

2) Karakteristik pekerjaan berpengaruh positif dan signifikan terhadap kinerja guru di Madrasah Tsanawiyah Negeri 3 Kabupaten Simalungun.

3) Kematangan emosi berpengaruh positif dan signifikan terhadap kinerja guru di Madrasah Tsanawiyah Negeri 3 Kabupaten Simalungun..

4) Kecerdasan emosional, karakteristik pekerjaan dan kematangan emosi berpengaruh positif dan signifikan terhadap kinerja guru di Madrasah Tsanawiyah Negeri 3 Kabupaten Simalungun.

\subsection{Tujuan Penelitian}

Tujuan penelitian ini adalah :

1) Untuk mengetahui pengaruh kecerdasan emosional terhadap kinerja guru di Madrasah Tsanawiyah Negeri 3 Kabupaten Simalungun.

2) Untuk mengetahui pengaruh karakteristik pekerjaan terhadap kinerja guru di Madrasah Tsanawiyah Negeri 3 Kabupaten Simalungun.

3) Untuk mengetahui pengaruh kematangan emosi terhadap kinerja guru di Madrasah Tsanawiyah Negeri 3 Kabupaten Simalungun.

4) Untuk mengetahui pengaruh kecerdasan emosional. karakteristik pekerjaan dan kematangan emosi terhadap kinerja guru di Madrasah Tsanawiyah Negeri 3 Kabupaten Simalungun.

\section{Metode Penelitian \\ 2.1. Populasi}

Populasi merupakan subjek penelitian dimana individu yang akan dikenai perilaku atau dapat dikatakan sebagai keseluruhan objek penelitian yang akan diteliti. Maka yang menjadi populasi dalam penelitian ini adalah seluruh guru di Madrasah Tsanawiyah Negeri 3 Kabupaten Simalungun yang berjumlah 39 orang, dimana kepala Madrasah dan peneliti tidak disertakan sebagai populasi. 
Tabel 1. Kerangka populasi berdasarkan status guru

\begin{tabular}{|c|l|c|}
\hline No & Keterangan & Jumlah (Orang) \\
\hline 1 & Guru tetap & 26 \\
\hline 2 & Guru honor & 13 \\
\hline \multicolumn{2}{|c|}{ Jumlah } & 39 \\
\hline
\end{tabular}

\subsection{Sampel}

Sedangkan sampel adalah sebagian dari jumlah dan karakteristik yang dimiliki oleh populasi. Dengan menggunakan teknik penarikan sampel yaitu total sampling atau metode sensus, maka sampel dalam penelitian ini berjumlah 39 orang guru Madrasah Tsanawiyah Negeri 3 Kabupaten Simalungun.

\subsection{Uji Normalitas}

Untuk mengetahui bentuk distribusi data, bisa dilakukan dengan grafik distribusi dan analisis statistik. Pengujian dengan distribusi dilakukan dengan melihat grafik histogram yang membandingkan antara dua observasi dengan distribusi yang mendekati distribusi normal. Distribusi normal akan membentuk satu garis lurus diagonal dan ploating data residual akan dibandingkan dengan garis diagonal. Jika distribusi atau residual normal, maka garis yang menggambarkan data yang sesungguhnya akan mengikuti garis diagonalnya. Uji normalitas dengan grafik dapat dilakukan dengan program SPSS dengan analisis grafik Normal Probability Plot

\subsection{Uji Autokorelasi}

Tabel 3. Uji Autokorelasi

\begin{tabular}{|c|c|c|c|c|c|c|}
\hline \multirow[b]{2}{*}{ Model } & \multicolumn{5}{|c|}{ Change Statistics } & \multirow{2}{*}{$\begin{array}{l}\text { Durbin- } \\
\text { Watson }\end{array}$} \\
\hline & $\begin{array}{l}\text { R Square } \\
\text { Change }\end{array}$ & F Change & df1 & df 2 & $\begin{array}{l}\text { Sig. F } \\
\text { Change }\end{array}$ & \\
\hline 1 & .639 & 20.691 & 3 & 35 & .000 & 2.018 \\
\hline
\end{tabular}

Berdasarkan Tabel 3, di atas diperoleh nilai Durbin-Watson (DW) sebesar 2.018, nilai ini berada pada kisaran $1.65<\mathrm{DW}<2.35$, maka dapat disimpulkan bahwa tidak terjadi autokorelasi pada model regresi yang diuji dalam penelitian ini.

\subsection{Uji Heteroskedastisitas}

Uji heteroskedastisitas dapat dilakukan dengan menggunakan grafik scatterplot antara nilai variabel terikat (ZSPRED) dengan residualnya (SRESID), dimana sumbu $X$ adalah yang diprediksi dan sumbu $\mathrm{Y}$ adalah residual.

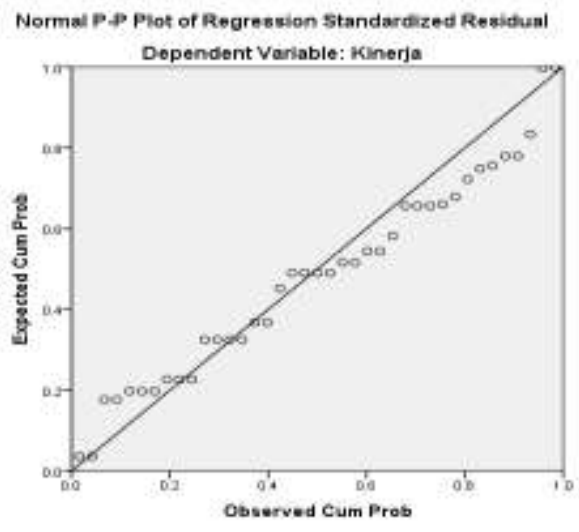

Gambar 1. Uji normalitas data

Berdasarkan gambar 1, diatas terlihat titiktitik dari ploating data residual berada di garis diagonal, hal ini dapat disimpulkan data yang diuji berdistribusi normal.

\subsection{Uji Multikolinearitas}

Berdasarkan Tabel 2, dibawah diperoleh nilai Tolerance Value diatas 0.1 yaitu 0.994, 0.736 , 0.729; hal ini menunjukan adanya korelasi yang cukup tinggi/kuat antara sesama variabel bebas dan nilai Variance Inflantion Factorrs (VIF) sebesar 1.059, 1.358, 1.371, dimana nilai VIF dari ketiga varibel bebas lebih kecil dari 10 dan dapat disimpulkan tidak terdapat multikolinieritas diantara ketiga variabel bebas yang diuji dalam penelitian ini.

Tabel 2. Uji multikolinieritas

\begin{tabular}{|l|c|c|}
\hline \multirow{2}{*}{ Variabel } & \multicolumn{2}{c|}{$\begin{array}{c}\text { Collinearity } \\
\text { Statistics }\end{array}$} \\
\cline { 2 - 3 } & Tolerance & VIF \\
\hline Kecerdasan emosional & 0.944 & 1.059 \\
\hline Karakteristik pekerjaan & 0.736 & 1.358 \\
\hline Kematangan emosi & 0.729 & 1.371 \\
\hline a Dependent Variable : Kinerja
\end{tabular}
Dasar pengambilan keputusan yang dapat diambil adalah sebagai berikut : 
a. Jika pola tertentu seperti titik-titik yang ada membentuk suatu pola yang teratur (bergelombang, melebar kemudian menyempit) maka telah terjadi heteroskedastisitas.

b. Jika tidak ada yang jelas serta titik-titik menyebar diatas dan dibawah angka nol pada sumbu $\mathrm{Y}$ maka tidak terjadi heteroskedastisitas

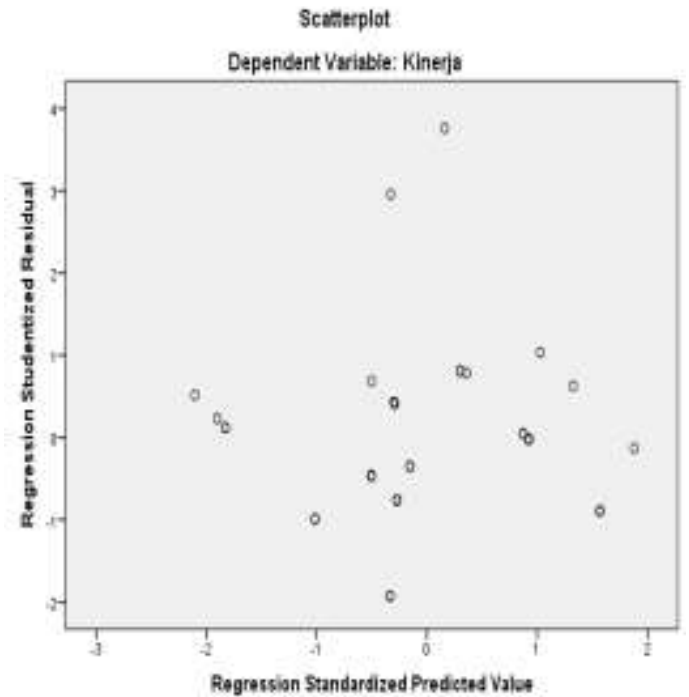

Gambar 2. Uji heteroskedastisitas

Tabel 4. Analisis regresi linier berganda

\begin{tabular}{|l|r|r|r|r|r|}
\hline \multirow{2}{*}{ Model } & \multicolumn{2}{|c|}{$\begin{array}{c}\text { Unstandardized } \\
\text { Coefficients }\end{array}$} & $\begin{array}{c}\text { Standardized } \\
\text { Coefficients } \\
\text { Beta }\end{array}$ & \multirow{2}{*}{$\mathrm{t}$} & \multirow{2}{*}{ Sig. } \\
\cline { 2 - 3 } & \multicolumn{1}{|c|}{$\mathrm{B}$} & Std. Error & & \\
\hline (Constant) & 3.720 & 5.133 & & .725 & .473 \\
\hline Kecerdasan emosional & .244 & .072 & .353 & 3.380 & .002 \\
\hline Karakteristik pekerjaan & .457 & .120 & .449 & 3.795 & .001 \\
\hline Kematangan emosi & .226 & .095 & .284 & 2.386 & .023 \\
\hline
\end{tabular}

Sumber : Hasil pengolahan data, 2020

Berdasarkan Tabel 4, diatas dapat dibuat persamaan regresi dalam penelitian ini sebagai berikut:

$$
\begin{gathered}
Y=3.720+0.244 X_{1}+0.457 X_{2}+0.226 X_{3} \\
+e
\end{gathered}
$$

Dari persamaan regresi linier berganda di atas dapat dijelaskan :

1) Nilai kinerja guru di Madrasah Tsanawiyah Negeri 3 Kabupaten Simalungun sebesar 3.720, dengan ketentuan nilai dari variabel bebas $\left(\mathrm{X}_{1}, \mathrm{X}_{2}\right.$, dan $\left.\mathrm{X}_{3}\right)$ diabaikan.

2) Nilai koefisien regresi $X_{1}$ (pengelolaan kelas) mempunyai nilai positif yaitu 0.244 , hal ini menunjukkan bahwa variabel pengelolaan kelas mempunyai pengaruh positif terhadap kinerja guru di Madrasah
Berdasarkan gambar 2, diatas, menunjukkan titik-titik yang menyebar, sehingga dapat disimpulkan tidak terjadi heteroskedastisitas di data penelitian ini.

\section{Hasil Pengujian Hipotesis}

3.1. Hasil Analisis Regresi Linear Berganda

Analisis regresi linier berganda dalam penelitian ini dapat dilihat dari persamaan regresinya, dan dari hasil pengolahan data diperoleh hasil berikut ini :
Tsanawiyah Negeri 3 Kabupaten Simalungun.

3) Nilai koefisien regresi $X_{2}$ (sertifikasi) mempunyai nilai positif yaitu 0.457 , hal ini menunjukkan bahwa variabel sertifikasi mempunyai pengaruh positif terhadap kinerja guru di Madrasah Tsanawiyah Negeri 3 Kabupaten Simalungun.

4) Nilai koefisien regresi $X_{3}$ (kepribadian) mempunyai nilai positif yaitu 0.226 , hal ini menunjukkan bahwa variabel kepribadian mempunyai pengaruh positif terhadap kinerja guru di Madrasah Tsanawiyah Negeri 3 Kabupaten Simalungun.

\subsection{Pengaruh Kecerdasan Emosional Terhadap Kinerja Guru di Madrasah}


Tsanawiyah Negeri 3 Kabupaten

Simalungun.

Untuk mengetahui pengaruh kecerdasan emosional terhadap kinerja guru di Madrasah
Tsanawiyah Negeri 3 Kabupaten Simalungun digunakan uji-t, sedangkan untuk melihat besarnya pengaruh digunakan nilai Beta atau Standardized Coefficient Beta.

Tabel. 5.Pengaruh kecerdasan emosional terhadap kinerja

\begin{tabular}{|l|r|r|r|r|r|}
\hline \multirow{2}{*}{ Model } & \multicolumn{2}{|c|}{$\begin{array}{c}\text { Unstandardized } \\
\text { Coefficients }\end{array}$} & \multirow{2}{*}{$\begin{array}{c}\text { Standardized } \\
\text { Coefficients } \\
\text { Beta }\end{array}$} & \multirow{2}{*}{$\mathrm{t}$} & \multirow{2}{*}{ Sig. } \\
\cline { 2 - 3 } & \multicolumn{1}{|c|}{$\mathrm{B}$} & \multicolumn{1}{|c|}{ Std. Error } & & \\
\hline$($ Constant $)$ & 3.720 & 5.133 & & .725 & .473 \\
\hline Kecerdasan emosional & .244 & .072 & .353 & 3.380 & .002 \\
\hline
\end{tabular}

a. Dependent Variable : Kinerja

Dari Tabel 5, diatas diperoleh nilai $\mathrm{t}_{\text {hitung }}$ sebesar 3.380. Penelitian ini menggunakan taraf signifikansi $(\alpha: 0.05)$ dan Derajat Kebebasan (DK) dengan ketentuan DK $=\mathrm{n}-2$, atau $39-2$ $=37$. Dengan ketentuan tersebut, diperoleh nilai $\mathrm{t}_{\text {tabel }}$ sebesar 2.026. Dengan kriteria hipotesis sebagai berikut :

Jika nilai $t_{\text {hitung }}>t_{\text {tabel}}$, maka hipotesis penelitian diterima.

Jika nilai $t_{\text {hitung }}<t_{\text {tabel}}$, maka hipotesis penelitian ditolak.

Dari hasil pengolahan data diperoleh nilai $t_{\text {hitung }}>t_{\text {tabel }}(3.380>2.042)$ dan nilai signifikasi lebih kecil dari nilai $\alpha: 0.05$ yaitu $0.002<0.05$, sehingga hipotesis yang diajukan dalam penelitian ini diterima. Artinya variabel kecerdasan emosional secara partial berpengaruh positif dan signifikan terhadap kinerja guru di Madrasah Tsanawiyah Negeri 3 Kabupaten Simalungun. Besarnya pengaruh variabel kecerdasan emosional terhadap kinerja guru di Madrasah Tsanawiyah Negeri 3 Kabupaten Simalungun sebesar 0.353 atau
$35.30 \%$. Hasil penelitian ini sejalan dengan hasil penelitian Devi, R. (2012); Fauzi, A. (2013); Firdaus, D. (2012) dan Lisda, R. (2012), yang mana kesemuanya menyatakan kecerdasan emosional berpengaruh positif dan signifikan terhadap kinerja. Deskripsi dari hasil penelitian ini menjelaskan jika guru mempunyai tingkat kecerdasan emosional dengan baik, maka akan berdampak positif untuk meningkatkan kinerja guru, begitu juga sebaliknya jika guru kurang mampu menggunakan kecerdasan emosional dengan baik maka akan berdampak pada penurunan kinerja guru.

\subsection{Pengaruh Karakteristik Pekerjaan Terhadap Kinerja Guru di Madrasah Tsanawiyah Negeri 3 Kabupaten Simalungun.}

Untuk mengetahui pengaruh karakteristik pekerjaan terhadap kinerja guru di Madrasah Tsanawiyah Negeri 3 Kabupaten Simalungun digunakan uji-t, sedangkan untuk melihat besarnya pengaruh digunakan nilai Beta atau Standardized Coefficient Beta.

Tabel. 6. Pengaruh karakteristik pekerjaan terhadap kinerja

\begin{tabular}{|c|c|c|c|c|c|}
\hline \multirow[t]{2}{*}{ Model } & \multicolumn{2}{|c|}{$\begin{array}{l}\text { Unstandardized } \\
\text { Coefficients }\end{array}$} & \multirow{2}{*}{$\begin{array}{c}\text { Standardized } \\
\text { Coefficients } \\
\text { Beta }\end{array}$} & \multirow[t]{2}{*}{$\mathrm{t}$} & \multirow[t]{2}{*}{ Sig. } \\
\hline & B & Std. Error & & & \\
\hline (Constant) & 3.720 & 5.133 & & .725 & .473 \\
\hline Karakteristik pekerjaan & .457 & .120 & .449 & 3.795 & .001 \\
\hline
\end{tabular}

Dari Tabel 6, diatas diperoleh nilai $\mathrm{t}_{\text {hitung }}$ sebesar 3.795. Penelitian ini menggunakan taraf signifikansi $(\alpha: 0.05)$ dan Derajat Kebebasan (DK) dengan ketentuan DK $=\mathrm{n}-2$, atau $39-2$ $=37$. Dengan ketentuan tersebut, diperoleh nilai $t_{\text {tabel }}$ sebesar 2.026. Dengan kriteria hipotesis sebagai berikut :

Jika nilai $t_{\text {hitung }}>t_{\text {tabel }}$, maka hipotesis penelitian diterima.
Jika nilai $t_{\text {hitung }}<t_{\text {tabel }}$, maka hipotesis penelitian ditolak.

Dari hasil pengolahan data diperoleh nilai $t_{\text {hitung }}>t_{\text {tabel }}(3.795>2.042)$ dan nilai signifikasi lebih kecil dari nilai $\alpha: 0.05$ yaitu $0.001<0.05$, sehingga hipotesis yang diajukan dalam penelitian ini diterima. Artinya variabel karakteristik pekerjaan secara partial berpengaruh positif dan signifikan terhadap kinerja guru di Madrasah Tsanawiyah Negeri 3 
Kabupaten Simalungun. Besarnya pengaruh variabel karakteristik pekerjaan terhadap kinerja guru di Madrasah Tsanawiyah Negeri 3 Kabupaten Simalungun sebesar 0.449 atau $44.90 \%$. Hasil penelitian ini sejalan dengan hasil penelitian Firman (2011) dan Hartiwi (2016), yang mana keduanya menyatakan karakteristik pekerjaan berpengaruh positif dan signifikan terhadap kinerja. Deskripsi dari hasil penelitian ini jika karakteristik pekerjaan sudah sesuai dengan skill guru maka akan berdampak peningkatan kinerjanya, begitu juga sebaliknya karakteristik pekerjaan tidak sesuai dengan skill yang dimiliki guru, maka kinerja guru akan menurun.

\subsection{Pengaruh Kematangan Emosi Terhadap Kinerja Guru di Madrasah Tsanawiyah Negeri 3 Kabupaten Simalungun \\ Untuk mengetahui pengaruh kematangan} emosi terhadap kinerja guru di Madrasah Tsanawiyah Negeri 3 Kabupaten Simalungun digunakan uji-t, sedangkan untuk melihat besarnya pengaruh digunakan nilai Beta atau Standardized Coefficient Beta.

Tabel. 7. Pengaruh kematangan emosi terhadap kinerja

\begin{tabular}{|c|c|c|c|c|c|}
\hline \multirow[t]{2}{*}{ Model } & \multicolumn{2}{|c|}{$\begin{array}{c}\text { Unstandardized } \\
\text { Coefficients }\end{array}$} & \multirow{2}{*}{$\begin{array}{c}\text { Standardized } \\
\text { Coefficients } \\
\text { Beta }\end{array}$} & \multirow[t]{2}{*}{$\mathrm{t}$} & \multirow[t]{2}{*}{ Sig. } \\
\hline & B & Std. Error & & & \\
\hline (Constant) & 3.720 & 5.133 & & .725 & .473 \\
\hline Kematangan emosi & .226 & .095 & 284 & 2.386 & .023 \\
\hline
\end{tabular}

Dari Tabel 7, diatas diperoleh nilai $\mathrm{t}_{\text {hitung }}$ sebesar 2.386. Penelitian ini menggunakan taraf signifikansi $(\alpha: 0.05)$ dan Derajat Kebebasan (DK) dengan ketentuan DK $=\mathrm{n}-2$, atau $39-2$ $=37$. Dengan ketentuan tersebut, diperoleh nilai $t_{\text {tabel }}$ sebesar 2.026.. Dengan kriteria hipotesis sebagai berikut :

Jika nilai $t_{\text {hitung }}>t_{\text {tabel }}$, maka hipotesis penelitian diterima.

Jika nilai $\mathrm{t}_{\text {hitung }}<\mathrm{t}_{\text {tabel}}$, maka hipotesis penelitian ditolak.

Dari hasil pengolahan data diperoleh nilai $t_{\text {hitung }}>t_{\text {tabel }}(2.386>2.042)$ dan nilai signifikasi lebih kecil dari nilai $\alpha: 0.05$ yaitu $0.023<0.05$, sehingga hipotesis yang diajukan dalam penelitian ini diterima. Artinya variabel kematangan emosi secara partial berpengaruh positif dan signifikan terhadap kinerja guru di Madrasah Tsanawiyah Negeri 3 Kabupaten Simalungun. Besarnya pengaruh variabel kematangan emosi terhadap kinerja guru di Madrasah Tsanawiyah Negeri 3

Kabupaten Simalungun sebesar 0.284 atau $28.40 \%$. Hasil penelitian ini sejalan dengan

Tabel 8. Pengaruh kecerdasan emosional, karakteristik pekerjaan dan kematangan emosi terhadap kinerja

\begin{tabular}{|l|l|r|r|r|r|c|}
\hline \multirow{3}{*}{ Model } & & $\begin{array}{c}\text { Sum of } \\
\text { Squares }\end{array}$ & \multicolumn{1}{c|}{ df } & \multicolumn{1}{c|}{$\begin{array}{c}\text { Mean } \\
\text { Square }\end{array}$} & \multicolumn{1}{c|}{ F } & \multicolumn{1}{c|}{ Sig. } \\
\hline \multirow{4}{*}{1} & Regression & 195.606 & 3 & 65.202 & 20.691 & $.000^{\mathrm{a}}$ \\
\cline { 2 - 7 } & Residual & 110.291 & 35 & 3.151 & & \\
\cline { 2 - 7 } & Total & 305.897 & 38 & & & \\
\hline
\end{tabular}

Dependent Variable : Kinerja hasil penelitian Endah Susilowati (2013), dan Umit S. Bititci (2015), yang mana keduanya menyatakan kematangan emosi berpengaruh positif dan signifikan terhadap kinerja. Deskripsi dari hasil penelitian ini menjelaskan bahwa jika guru mampu mengdalikan emosinya dengan yang baik dalam mengajar maka akan berdampak pada peningkatan kinerja guru, begitu juga sebaliknya jika guru tidak mampu mengdalikan emosinya dalam mengajar maka berdampak pada penurunan kinerjanya.

\subsection{Pengaruh Kecerdasan Emosional, Karakteristik Pekerjaan Dan Kematangan Emosi Terhadap Kinerja Guru Di Madrasah Tsanawiyah Negeri 3 Kabupaten Simalungun}

Untuk mengetahui pengaruh kecerdasan emosional, karakteristik pekerjaan dan kematangan emosi terhadap kinerja guru di Madrasah Tsanawiyah Negeri 3 Kabupaten Simalungun digunakan uji-F. 
Dari Tabel 8, di atas diperoleh nilai $\mathrm{F}_{\text {hitung }}$ sebesar 20.691. Penelitian ini menggunakan taraf signifikansi $(\alpha: 0.05)$ dan Derajat Kebebasan (DK) dengan ketentuan numerator : jumlah variabel -1 atau $4-1=3$, dan jumlah sampel dikurang 4 atau $39-4=35$. Dengan ketentuan tersebut, diperoleh nilai $\mathrm{F}_{\text {tabel }}$ sebesar 2.87. Dengan kriteria pengujian hipotesis sebagai berikut :

Jika $\mathrm{F}_{\text {hitung }}>\mathrm{F}_{\text {tabel}}$, maka hipotesis penelitian diterima.

Jika $F_{\text {hitung }}<\mathrm{F}_{\text {tabel }}$, maka hipotesis penelitian ditolak.

Dari hasil perhitungan diperoleh nilai $\mathrm{F}_{\text {hitung }}>\mathrm{F}_{\text {tabel }}(20.691>2.87)$ dan nilai signifikasi $0.00<0.05$, sehingga hipotesis yang diajukan dalam penelitian ini diterima. Artinya variabel kecerdasan emosional, karakteristik pekerjaan dan kematangan emosi secara

Tabel 9. Model summary ${ }^{\mathrm{b}}$ pengaruh kecerdasan emosional, karakteristik pekerjaan dan kematangan emosi terhadap kinerja

\begin{tabular}{|l|l|r|r|r|}
\hline Model & $R$ & $R$ Square & $\begin{array}{c}\text { Adjusted } R \\
\text { Square }\end{array}$ & $\begin{array}{c}\text { Std. Error of the } \\
\text { Estimate }\end{array}$ \\
\hline 1 & $.800^{\mathrm{a}}$ & .639 & .609 & 1.77515 \\
\hline
\end{tabular}

Dependent Variable : Kinerja

Besarnya Tabel 9, diatas diperoleh nilai Adjusted Rsquare $\left(\mathrm{r}^{2}\right)$ sebesar 0.609. Nilai tersebut mempunyai maksud bahwa pengaruh variabel kecerdasan emosional, karakteristik pekerjaan dan kematangan emosi terhadap kinerja guru di Madrasah Tsanawiyah Negeri 3 Kabupaten Simalungun sebesar $60.90 \%$, sedangkan sisanya sebesar $39.10 \%$ dipengaruhi oleh faktor-faktor lain yang tidak diteliti. Dengan kata lain variabel kinerja guru di Madrasah Tsanawiyah Negeri 3 Kabupaten Simalungun dapat diterangkan oleh variabel kecerdasan emosional, karakteristik pekerjaan dan kematangan emosi sebesar $60.90 \%$, sedangkan sisanya sebesar $39.10 \%$ disebabkan oleh variabel-variabel lain yang tidak diteliti.

\section{Kesimpulan}

Berdasarkan pada pembahasan pada bab sebelumnya, maka dapat ditarik kesimpulan dari penelitian ini sebagai berikut :

a. Variabel kecerdasan emosional secara partial berpengaruh positif dan signifikan terhadap kinerja guru di Madrasah Tsanawiyah Negeri 3 Kabupaten Simalungun.

b. Variabel karakteristik pekerjaan secara partial berpengaruh positif dan signifikan terhadap kinerja guru di Madrasah simultan berpengaruh positif dan signifikan terhadap kinerja guru di Madrasah Tsanawiyah Negeri 3 Kabupaten Simalungun. Dengan demikian model regresi ini sudah layak dan benar dan dapat disimpulkan bahwa variabel kecerdasan emosional, karakteristik pekerjaan dan kematangan emosi berpengaruh terhadap kinerja guru di Madrasah Tsanawiyah Negeri 3 Kabupaten Simalungun.

\subsection{Uji Determinan}

Uji determinan adalah untuk mengetahui seberapa besar pengaruh variabel kecerdasan emosional, karakteristik pekerjaan dan kematangan emosi terhadap kinerja guru di Madrasah Tsanawiyah Negeri 3 Kabupaten Simalungun, dan dapat dilihat dari model summary, khususnya nilai Adjusted Rsquare.
Tsanawiyah

Simalungun.

c. Variabel kematangan emosi secara partial berpengaruh positif dan signifikan terhadap kinerja guru di Madrasah Tsanawiyah Negeri 3 Kabupaten Simalungun.

d. Variabel kecerdasan emosional, karakteristik pekerjaan dan kematangan emosi secara simultan berpengaruh positif dan signifikan terhadap kinerja guru di Madrasah Tsanawiyah Negeri 3 Kabupaten Simalungun.

\section{DAFTAR PUSTAKA}

Agustian, Ary Ginanjar. (2011). Rahasia Sukses Membangun Kecerdasan Emosi dan Spiritual, ESQ: Emotional Spiritual Quotient berdasarkan 6 Rukun Iman dan 5 Rukun Islam. Jakarta: Arga Wijaya Persada

Chaplin (2011), Kamus Lengkap Psikologi, Diterjemahkan oleh Kartini Kartono, Jakarta, PT. Grafinda Raja Perkasa.

Deshwal, P. (2016). Impact of Emotional Intelligence on Organizational Performance. International Journal of Advanced Research in Management and Social Sciences Vol 5 No 1 
Devi, R. (2012). Pengaruh Kecerdasan Emosional terhadap Kinerja Pegawai. Jurnal Educhild Vol 01 No 1

Effendi Nur Hasan, Mulyoto, Nunuk Suryani, (2015), Jurnal Teknologi Pendidikan, Volume 1, No 2, Halaman 214-225

Fauzi, A. (2013). Pengaruh Kepemimpinan, Kecerdasan Emosional dan Motivasi terhadap Kepuasan Kerja Guru di SMA. Jurnal Manajemen Pendidikan Vol 1, No 1

Firdaus, D. (2012). Pengaruh Kecerdasan Emosional (EQ) dan Motivasi Belajar terhadap Hasil Belajar Biologi Siswa SMA 3 Negeri Kota Palopo. Jurnal pendidikan dan Pembelajaran Vol 19 No 2.

Firman (2011), PengaruhKarakteristik Pekerjaan terhadap Kepuasan KerjaPegawai di LingkunganPemkot Payakumbuh.TINGKAP Vol. VII No. 2 Th.2011

Goleman, Daniel. (2011). Emotional Intelligence, Kecerdasan Emosional Mengapa EI Lebih Penting daripada IQ. Jakarta: PT. Gramedia Pustaka Utama

Handoko, T. Hani (2013), Manajemen, Edisi 2, BPFE, Yogyakarta

Hartiwi (2016), Analisis Pengaruh Karakteristik Pekerjaan dan Kompetensi terhadap Kinerja Guru dengan Mediasi Kepuasan Kerja (Studi pada SMP Muhammadiyah Se Kabupaten Pati)

Hasibuan, Malayu, SP (2012), Manajemen Sumber Daya Manusia, PT. Bumi Akasara Jakarta.

Husnan, Keldjrachman Suad, (2004), Manajemen Personalia, Edisi ke Empat, BPFE Yogyakarta

Istijanto (2008). Riset Sumber Daya Manusia, Cara Praktis Mendeteksi Dimensi-Dimensi Kerja Pegawai, Cetakan Ketiga, PT Gramedia, Jakarta

Komaruddin (2007), Ensiklopedia Manajemen, Rineka Cipta, Jakarta

Kumar, V.V., Mehta, M., dan Maheshwari, N. (2013). Effect of Emotional Intelligence on the Achievement Motivation. Journal of the Indian Academy of Applied Psychology January 2013, Vol.39, No.1

Lisda, R. (2012). Pengaruh Kecerdasan Intelektual, Kecerdasan Emosi dan Kecerdasan Spiritual terhadap Kinerja Pegawai. Jurnal Majalah Ilmiah Informatika Vol 3 No.
Manullang (2011), Manajemen Pengantar Ekonomi Perusahaan, Edisi Revisi, Cetakan Ke Enam Belas, BPFE, Yogyakarta

Martoyo, Susili (2014), Manajemen Sumber Daya Manusia, Edisi Ketiga, Cetakan Keempat, Ghalia Jakarta

Moekijat (2011), Latihan dan Pengembangan Sumber Daya Manusia, Cetakan ke Empat, Maju Mundur, Bandung

Nitisemito S Alex (2011), Manajemen Personalia, Cetakan Keempat, Ghalia, Jakarta.

Rivai, Veithzal dan Sagala, Ella Jauvani. (2009). Manajemen Sumber Daya Manusia Untuk Perusahaan : Dari Teori ke Praktek. Jakarta : PT. Rajagrafindo Persada

Robbins, Stephen P (2012). Essentials of Organizational Behavior (Terjemahan), Edisi Kelima, Penerbit Erlangga, Jakarta

Santoso Singgih (2004), Buku Latihan SPSS Statistik Parametrik, PT. Alex Media Komputindo Gramedia Jakarta.

Schroeder, Roger G (2004), Manajemen Operasi, Jilid I Erlangga Jakarta

Schuler Randal S and Jackson Susan E, alih bahasa Prawira Hie (2011), Manajemen Sumber Daya Manusia, Penerbit Erlangga Jakarta

Sedarmayanti (2007). Manajemen Sumber Daya Manusia, Reformasi Birokrasi dan Manajemen Pegawai Negeri Sipil, PT Refika Aditama Bandung

Shapiro, L.E., 2003. Mengajarkan emotional intelligence pada anak, PT Gramedia Pustaka Utama, Jakarta

Siagian, SP (2003) Teori dan Praktek Pengambilan Keputusan, Cetakan II, CV. Haji Masagung, Jakarta

Smithson, Janet., Suzan Lewis (2007). Is job insecurity changing the psychological contract. Personnel Review ,29(6):1-15

Sudarma, Momon. (2013). Profesi Guru: Dipuji, Dikritisi dan Dicaci. Jakarta: RajaGrafindo Persada

Sugiyono. (2009). Metode Penelitian Kuantitatif dan Kualitatif dan R \& D. Bandung : Alfabeta

Sunarto dan Hartono Agung (2016), Perkembangan peserta Didik. Jakarta : PT Rineka Cipta.

Suparno, Paul (2013), Guru Demokrasi Di Era Reformasi Pendidikan. Jakarta : PT Gramedia.

Supeno, Hadi (2016), Potret Guru. Jakarta. Pustaka Sinar Harapan 
Suryana Sumantri (2012). Perilaku Organisasi. Bandung: Universitas Padjadjaran

Supriadi dan Sefnedi (2017), The effect of emotional intelligence and organizational cynicism on job performance: The role of motivation as mediator, IOSR Journal of Business and Management

Sutrisno, Edy (2014). Manajemen Sumber Daya Manusia, Kencana Prenada Media Group Jakarta

Swastha DH, Basu dan Ibnu Sukotjo (2000), Pengantar Bisnis Modern, Edisi Revisi Liberty Yogyakarta

Syah, Muhibbin (2014), Psikologi Pendidikan. Bandung: PT. Remaja Rosdakarya

Svyantek, D.J., 2003. Emotional Entellegence and Organizational Behavior The International Journal of Organization Analysis 11(3): 167-169

Terry George \& Rue, Leslie W alih bahasa Sadeli (2012), Dasar-Dasar Manajemen, Cetakan Ketujuh Bumi Aksara Jakarta
Triton PB(2006), SPSS 12.00 Terapan Riset Statistik Parametrik, Andi Yogyakarta.

Umit S. Bititci (2015), Value of maturity models in performance measurement, International Journal of Production Research, Vpl. 53:Issue: 10

Undang-Undang Republik Indonesia Nomor 20 Tahun 2003 Tentang Sistem Pendidikan Nasional. Jakarta

Undang-Undang Nomor 14 Tahun 2005 tentang penjelasan Undang-undang Guru dan Dosen

Uzer, Moh Anoraga. (2013), Menjadi Guru Profesional. Bandung : PT Remaja Rosdakarya

Wibowo (2014). Manajemen Kinerja, Edisi Kedua, PT RajaGrafindo Persada, Jakarta

Wiwik Indah Asmoro Yani dan Kamsih Astuti, (2015), Hubungan Antara Motivasi Berprestasi Dan Kematangan Emosi Dengan Kreativitas Pada Guru TK Pembina Purworejo, InSight, Vol. 17 No. 1, Februari 2015 ISSN: 1693-2552 